\title{
Dynein Heavy Chain 9, Axonemal
}

National Cancer Institute

\section{Source}

National Cancer Institute. Dynein Heavy Chain 9, Axonemal. NCl Thesaurus. Code C150221.

Dynein heavy chain 9, axonemal (4486 aa, $\sim 512 \mathrm{kDa}$ ) is encoded by the human DNAH9 gene. This protein is involved in the mediation of ciliary and flagellar movement. 